\title{
Kultur pop dan diskursus ideologi kecantikan pada iklan di televisi
}

\author{
Imam Nuraryo ${ }^{1}$ \\ ${ }^{1}$ Institut Bisnis dan Informatika Kwik Kian Gie, Jakarta, Indonesia
}

\begin{abstract}
ABSTRAK
Saat ini televisi telah menjadi saluran untuk membangun gambaran ideal mengenai dunia. Salah satunya adalah citra kecantikan seorang wanita. Iklan di televisi telah merekayasa hal tersebut dalam penyampaian pesannya. Kebanyakan mereka menampilkan fisik wanita secara ideal adalah memiliki kulit bersih (putih), tubuh yang yang langsing, dan memiliki rambut hitam yang panjang. Metode penelitian yang digunakan adalah kualitatif deskriptif. Teknik pengumpulan data yang dilakukan adalah observasi pada tiga buah iklan televisi yakni iklan Pond's versi fotografer, iklan WRP Lose Weight dan iklan shampo Pantene Hair Fall pro Vitamin versi Maudy Ayunda. Hasil penelitian ini adalah bahwa ketiga iklan tersebut memberikan gambaran yang ideal adalah dengan menampilkan tubuh yang langsing, rambut kuat adalah rambut yang hitam dan dan kulit yang cantik adalah kulit yang putih. Ketiga hal tersebut menjelma menjadi diskursus dominan fisik perempuan yang ideal di benak khalayak. Diskursus ini mampu meminggirkan diskursus alternatif yakni bagi para perempuan yang tidak berkulit bening, berambut hitam berkilau dan bertubuh tidak langsing. Konsekuensinya adalah bagi para perempuan yang tak mendapatkan "status" sebagaimana yang telah justifikasi iklan, akan kehilangan kepercayaan pada diri kuasa atas fisiknya serta seiring berjalannya waktu memudarnya identitas ciri akan fisiknya.
\end{abstract}

Kata-kata Kunci: Iklan; televisi; kultur pop; diskursus; kecantikan

\section{Pop culture and beauty ideology discourse on television advertisements}

\begin{abstract}
Television nowadays has been a channel to build a special portrayal about the world. Among other thing is the beauty image of women. Advertisements in television create it in their messages. Most of them show women ideally have with clear (white) skin, slim in her body and having long black hair physically. Television advertising is strongly related to modern pop culture. The research method used is descriptive qualitative. Data collection techniques carried out were observations on three television advertisements namely the photographer's version of Pond's ad, the WRP Lose Weight advertisement, and the Maudy Ayunda version of Pantene Hair Fall pro Vitamin shampoo ad. The results of this study are that the three advertisements provide an ideal picture is to display a slim body, strong hair is black hair and beautiful skin is white skin. To sum up, these three things became the ideal female dominant discourse in the minds of the public. This discourse is able to marginalize alternative discourse, namely for women who are not clear skinned, shiny black haired and not slim. Consequently, for women who do not get "status" as they have justified the advertisement, they will lose confidence in their power over their physicality and as time goes by the diminishing identity of their physical characteristics.
\end{abstract}

Keywords: Advertisement; television; pop culture; discourse; beauty

Korespondensi: Dr. Imam Nuraryo, M.A. (Comms). Institut Bisnis dan Informatika Kwik Kian Gie, Jln Yos Sudarso, Kav 87 Jakarta Utara. Email: imam@kwikkiangie.ac.id 


\section{PENDAHULUAN}

Siaran televisi sejatinya tidak hanya menyentuh sisi psikologis khalayak sebagaimana yang sering terlihat pada tingginya frekuensi masyarakat dalam mendiskusikan program-program yang ditonton. Lebih dari aktivitas itu, bahwa televisi sesungguhnya hadir dalam bentuk wujudiahnya di masyarakat. Fakta membuktikan bahwa sebagian masyarakat menyimpan televisi di rumah mereka yang menunjukkan bahwa betapa televisi telah menjadi bagian yang tak terpisahkan dalam lini hidup manusia. Kehadiran televisi juga disebut membawa beberapa perbedaan dalam interaksi dan relasi antar anggota keluarga (Permana, dkk., 2019).

Marshall McLuhan menyatakan bahwa televisi sebagai "Media Panas" merupakan media yang penting dan paling efektif untuk membangkitkan dan sekaligus melumpuhkan kesadaran massa dalam jangka waktu yang tidak dapat ditentukan. Itulah yang menjadi dasar logika dasar televisi yang bertujuan menghipnotis individu sehingga tunduk di bawah kekuasaannya, yang kemudian digiring perlahan untuk berduyun-duyun mengonsumsi produk-produk yang ditawarkan (McQuail, 2002:302).

Dalam perjalanan sejarah mengenai konsep kecantikan. Standard kecantikan yang ideal akan setiap saat dikonstruksikan sesuai dengan minat dari suatu kalangan masyarakat tertentu dan dalam periode masa tertentu. Salah satu alat untuk melakukan konstruksi tersebut diantaranya adalah melalui iklan televisi. Iklan menayangkan figur mengenai kecantikan yang merupakan standard ideal yang akan ditanamkan pada benak khalayak. Kecantikan sebagai salah satu makna kesehatan yang tidak hanya sebagai budaya namun telah menjadi gaya hidup (life style) disebut Hidayat dan Abdullah sudah menjadi industri tersendiri dalam kehidupan modern sekarang (Hidayat \& Abdullah, 2014).

Iklan yang ditayangkan terus menerus menimbulkan potensi dalam menggiring pemirsa untuk tunduk pada aneka standar nilai yang ditetapkan. Sebagai contoh, ketika seseorang perempuan menyaksikan iklan pemutih wajah, iklan pelangsing tubuh, iklan parfum atau iklan pewarna rambut, dan iklan tersebut menyatakan bahwa wajah yang putih merupakan wajah cantik yang ideal, tubuh langsing adalah tubuh yang dapat memikat, wangi tubuh adalah merupakan suatu keharusan dan rambut hitam yang lurus adalah rambut wanita yang indah, tentu semua itu tidak lepas dari motif ideologis tertentu di balik penyajian tersebut.

Dengan demikian, citra tubuh perempuan yang ideal yang disebarkan melalui iklan kecantikan di televisi menawarkan suatu ideologi uniformasi yang "harus" dipatuhi oleh seluruh pemirsa yang menontonnya. Dengan dukungan efek audio visual televisi yang makin canggih, jalinan cerita dalam iklan mampu menembus ke dalam alam bawah sadar pemirsanya sampai-sampai hal tersebut (nilai yang terdapat pada pesan iklan) menjadi suatu "kebenaran", yang harus segera ditindaklanjuti.

Maka tak heran jika saat ini makin marak kaum hawa rajin mendatangi salon kecantikan, membeli produk-produk kecantikan yang harganya tidak murah, bahkan rela pergi jauh ke negeri Ginseng untuk melakukan operasi plastik atau sekedar mempermak wajahnya dengan produk - produk dari negara tersebut yang mereka anggap memiliki kualitas yang sangat baik, hanya karena pengaruh pesan iklan di televisi.

Penggambaran (potrayal) perempuan dalam iklan kecantikan di televisi, sebenarnya merupakan ilustrasi gamblang manifestasi dari kultur pop yang dimediasi oleh media elektronik. Banyaknya tayangan iklan kosmetika atau obatobatan yang mampu menggiring para kaum ibu untuk mengikuti apa yang dimaui oleh pihak produsen melalui iklan televisi. Mirisnya, konsumen kaum ibu ini tidak secara sadar bahwa hal tersebut sebenarnya bukan motif dari diri sendiri atau justru bisa jadi ada unsur-unsur membahayakan diri dari kosmetik tersebut yang mungkin mengandung bahan berbahaya.

Hal ini dapat menjadi bukti bahwa kemenangan mitos kecantikan popular dalam perspektif global sudah pasti tidak dapat dilepaskan dari peran televisi. Jika kulit putih bersih dan rambut hitam lurus serta tubuh 
langsing merupakan citra cantik menurut industri kosmetika Asia Timur, maka akan berbeda belahan dunia barat yang menyatakan cantik itu adalah identik dengan kulit yang kecoklatan. Berbeda lagi mungkin jika di Afrika atau mikronesia yang menyatakan cantik itu ditandai dengan tubuh wanita yang subur.

Televisi dipandang oleh industri kosmetika sebagai sebuah showbiz karena televisi dianggap bukanlah seonggok benda tak bernyawa. Televisi dianggap sebagai media pembentuk realitas khalayak yang mampu "berinteraksi" dengan manusia. Sara Mills (dalam Eriyanto, 2001) menyatakan bahwa dalam wacana feminism, iklan kecantikan di televisi digunakan sebagai upaya untuk mengonstruksikan pola pikir dan gaya hidup manusia, dan tidak sebatas sebagai media promosi produk.

Televisi adalah salah satu media yang ampuh dalam mendesiminasi ide dan gagasan, oleh karena daya jangkaunya luas dan nyaris tak berbatas. Mengonsumsi pesan melalui televisi, tak memerlukan usaha bagi khalayaknya sebagaimana mendatangi bioskop atau konser. Nilai lebih yang dimiliki televisi telah membuka peluang lebar untuk iklan, terutama iklan produk kecantikan untuk mengonstruksi kecantikan yang paripurna. Suatu konstruksi dapat dimengerti keberadaannya via organisasi sosial yang menjadi kerangka kelompok yang terdiri dari individu-individu penentunya.

Media massa khususnya televisi dan kaum hawa merupakan dua entitas yang selalu berkaitan terlebih jika dihubungkan dengan representasi perempuan dalam media massa elektronik. Secara umum, gambaran kaum hawa di media selalu diwarnai oleh aneka imaji yang mendorong peningkatan penjualan produk. Perihal tersebut dapat kritisi dari program iklan yang mengekspos tubuh perempuan. Kaum hawa digiring dengan kriteria perempuan yang cantik yang dianggap ideal oleh kelompok masyarakat tertentu.

Dalam kajian feminis mengindikasikan bahwa konstruksi kecantikan yang sempurna tersebut berbasiskan ideologi maskulinitas, yakni dengan menumbuhkan perasaan "cemas" terhadap "kekurangan-kekurangan" yang ada pada tubuh perempuan. Disamping itu, faktor ekonomi juga menjadi pendorong konstruksi kecantikan ideal masa kini.

Atas nama kepentingan ekonomi, maka perusahaan melalui iklan, akan terus menerus menampilkan gambaran kecantikan perempuan yang ideal (menurut mereka) sehingga mendorong para perempuan untuk selalu menyempurnakan kecantikannya dengan mengikuti realita yang tersaji. Dengan kata lain, terdapat kesinambungan antara pembentukan citra cantik ideal yang ditampilkan di iklan dan komoditas. Siklus tersebut menggambarkan posisi perempuan menempati posisi triangular, yakni "penjual/penggoda", komoditi atau barang dagangan, sekaligus konsumen.

Dalam beberapa kesempatan, penulis pernah bertanya kepada beberapa teman perempuan apakah penggunaan kosmetika dalam keseharian merupakan suatu keharusan bagi seorang perempuan. Mereka rata-rata menjawab bisa ya bisa tidak. Ketika dirinya sudah cantik tak perlu menggunakan kosmetik, sebaliknya jika kurang cantik, maka bolehlah ia menggunakannya. Lantas penulis bertanya kembali apakah menjadi cantik haruskah dengan berkosmetika? Mereka rata-rata menjawab iya, dan yang lebih mengejutkan bahwa tampil cantik itu perlu karena mereka juga memerlukan pujian atau ketertarikan dari lawan jenis. Jawaban mereka jelas menunjukkan bahwa secara tidak sadar (ataupun tidak) kaum hawa akan menyesuaikan dengan standar general yang telah dikonstruksikan oleh iklan-iklan di televisi.

\section{METODE PENELITIAN}

Metode yang digunakan dalam penelitian ini adalah deskriptif kualitatif. Metode kualitatif dilakukan untuk menyingkap dan memahami apa yang tersembunyi di balik suatu gejala sosial yang sedikit atau belum diketahui. Teknik pengumpulan data yang digunakan dalam penulisan artikel ini adalah observasi pada sejumlah iklan kosmetika yang ditayangkan di televisi. Interpretasi dan analisis terhadap beberapa iklan dilakukan menggunakan pendekatan wacana kritis.

Wacana Kritis Foucault dipilih dengan 
pertimbangan bahwa pemikiran Foucault memberikan pemahaman mengenai konsep konstruksi persepsi sebagai inti komunikasi dari teks dan media pada pemirsanya. Iklan kecantikan sebagai diskursus memberikan deskripsi tentang garis besar persepsi dan keterkaitannya tentang relasi kuasa serta pengetahuan dalam sebuah alur cerita (Haryatmoko, 2010).

Sumber data penelitian ini adalah tiga buah video yang menyajikan iklan kosmetika kecantikan dengan merk yakni Pond's White Beauty, WRP Lose Weight, dan Pantene. Teknik pengumpulan data yang dilakukan adaah menggunakan studi dari berbagai literature yang terkait dengan gambaran kecantikan ideal yang memang dikonstruksikan oleh iklan Televisi, yang telah terdokumentasi oleh media social Youtube.

\section{HASIL DAN PEMBAHASAN}

Kultur atau Kebudayaan pada hakekatnya adalah hasil dari pemikiran-pemikiran manusia yang mewujud dalam perilaku dan tindaktanduk keseharian. McIver (dalam Soekanto, 2002) menyatakan bahwa kultur adalah ekspresi pikiran, emosi dan jiwa dalam cara-cara hidup dan berpikir, pergaulan hidup, seni susastra, perilaku menjalankan agama, rekreasi yang dapat memenuhi kebutuhan hidup manusia. Kultur juga dapat menjadi sebuah panduan bagi sekelompok masyarakat untuk bertindak dan berperilaku. Semakin kompleks masyarakat, maka semakin kompleks pula perilaku komunikasi yang dijalankan.

Komunikasi menjadi alat bagi kultur untuk dapat mempertahankan keberadaannya dan dan memastikan bahwa hal tersebut melalui pewarisan sosial. Komunikasi dapat pula menjadi media pewarisan budaya tandingan (Counter culture media) yang tumbuh mengakar sebagai alternatif dari budaya adiluhung yang dimiliki oleh masyarakat. Budaya adiluhung merupakan salah satu aspek kebudayaan masyarakat yang eksistensinya berasal dari nilai-nilai kearifan lokal dan mendasar yang dimiliki oleh kebudayaan itu sendiri.

Budaya adiluhung menampakkan diri pada salah satunya adalah alat-alat musik tradisional, pagelaran seni wayang, dan seni pahat. Namun demikian, sebagai akibat akselerasi dan perilaku instan dari masyarakat, terutama kaum milenial, budaya adiluhung ini mendapatkan tandingan dari budaya popular atau kultur pop. Menurut McDonald (Strinati, 2003) kultur pop atau kultur massa bermakna sebuah kekuatan dinamis yang mampu menghancurkan batasan- batasan tradisional, selera rakyat dan mengaburkan segala macam perbedaan.

Frasa "kultur pop" yang awal katanya adalah "budaya rakyat" (do povo) menurut budaya latin maknanya adalah suatu kebudayaan yang berkembang dari kreativitas orang kebanyakan. Kultur pop berasal dari rakyat dan bukan diberikan kepada mereka. Perspektif ini telah mendobrak perbedaan antara industri budaya dan penerima budaya. Kita ini semua dapat dianggap memroduksi kultur pop. Ini sejalan dengan pendapat dari Lull yang menyatakan bahwa mengonstruksi kultur pop merupakan pelaksanaan kekuasan kultur.

Dalam Mazhab Frankfurt, dinyatakan bahwa kultur pop merupakan pandangan yang menyatakan bahwa kultur berlandaskan komoditas sebagai sesuatu yang tidak otentik, bersifat manipulatif dan tidak memuaskan. Alasan rasionalnya adalah bahwa Mass Culture kapitalis yang terkomodifikasi tidak otentik, sebab tidak dihasilkan oleh masyarakat yang sejati. Manipulatif karena tujuan utama dari kultur pop ini agar dapat "dibeli". "Tidak memuaskan" karena produk kultur ini sangat mudah dikonsumsinya, juga tidak menetapkan persyaratan untuk terlalu bersusah payah dalam usaha memahaminya.

Kultur pop juga menepiskan segala budaya yang telah terbentuk sejak lama dan menghasilkan apa yang disebut dengan kultur penyeragaman (homogeneity culture) yang anti kemapanan, memberikan alternatif bagi masyarakat untuk melakukan perubahan dan selanjutnya menjadi unifikator unsur-unsur masyarakat yang terpisahkan oleh kelas dan status sosial ke dalam satu komunitas besar yakni komunitas maya. Masyarakat yang terpisah-pisah tersebut kemudian dipertemukan oleh kultur pop yang terdesiminasi baik melalui 
media massa maupun media dalam jaringan.

Kultur pop muncul ketika perbedaan antara budaya elite kalangan atas dan ceritera ceritera rakyat (Folklore) mulai menipis seiring perkembangan demokrasi, perkembangan teknologi sebagai akibat revolusi industri, dan meningkatnya taraf pendidikan masyarakat sejak awal abad ke-19. Wilson lebih lanjut menerangkan pula bahwa produk kultur pop memiliki karakteristik yakni memiliki standar tersendiri, mengandung stereotip, dan manipulasi pada produk-produk yang bernilai consumers goods (Fiske dan Hartley, 2003).

McQuail berpendapat bahwa kultur pop memiliki ciri asli yang bersifat spontan dan eksistensinya berlangsung terus menerus dalam kehidupan sosial dengan bentuk yang variatif dan heterogen (McQuail, 2002). Masyarakat yang dinamis, berkembang dan berubah akan terus menerus melahirkan kultur pop. Dengan demikian, kultur pop ini akan selalu berkaitan dengan masyarakat modern sebagai sasaran dari media massa maupaun media virtual.

Kultur pop juga melahirkan kultur konsumerisme dimana cara hidup yang dilakoni oleh masyarakat melalui perantara televisi, radio, film dan internet. Media tersebut telah menjadi alat kapitalis untuk menginfiltrasi pesan - pesan konsumtif kepada masyarakat sehingga mendorong gaya hidup konsumptif adalah merupakan suatu keharusan. Hal ini mendorong kultur ini akhirnya mendarah daging pada masyarakat global, tak terkecuali bagi bangsa Indonesia.

Michael Foucault menyatakan bahwa terdapat motif-motif tertentu pada suatu media atau teks yang disebut dengan produksi kekuasaan. Produksi kekuasaan bermakna bahwa kekuasaan tidak bertumpu pada satu titik sentral termasuk tidak hanya pada pihak-pihak yang dominan, melainkan tersebar di seluruh masyarakat (dengan kata lain tak seorangpun yang memiliki). Lechte mengatakan bahwa kuasa bukanlah milik raja, boss, presiden atau pejabat, tetapi dalam bentuk strategi (Burton, 2008).

Kekuasaan tidak bekerja melalui penindasan atau represi, melainkan melalui normalisasi yang positif dan produktif melalui wacana/diskursus. Iklan televisi adalah salah satu saluran yang menyebarkan kuasa (strategi) mengenai kelaziman tubuh perempuan. Produksi kekuasaan yang terjadi kemudian adalah munculnya strategi untuk mengembangkan wacana "langsing", "kulit putih", "tubuh wangi" atau "rambut lurus hitam panjang" yang muncul terus menerus sehingga secara tidak sadar masyarakat menganggap fisik perempuan adalah selayaknya seperti gambaran yang mereka tampilkan. Proses itulah berlangsungnya strategi kuasa yang diproduksi secara kontinyu.

Diskursus yang dikembangkan ini secara perlahan-lahan akan menampakkan kategorisasi, seperti halnya perilaku baik atau buruk yang pada akhirnya mengendalikan perilaku masyarakat yang menganggap bahwa kebenaran itu telah diputuskan. Berdasarkan hal tersebut di atas maka bukan lagi fisik tubuh yang hendak disentuh oleh kuasa, namun juga jiwa, kesadaran, pikiran, serta karsa individu.

Foucault juga menyatakan bahwa memang diakui bahwa masyarakat modern telah diwarnai dengan aneka fenomena seks yang dinilai bertentangan dengan etika dan norma sosial. Terdapat empat fenomena seks yang menjadi akibat salah memanfaatkan media massa, khususnya televise, seturut logika kapitalisme dan penafsiran yang serampangan terhadap makna kebebsan pribadi. Empat fenomena tersebut adalah sex appeal dalam iklan, seks dalam cyberspace, homoseksualitas dan free sex.

Masalah stereotip daya tarik seksualitas serta organ-organ tubuh manusia yang mempunyai sex appeal tinggi, merupakan salah satu realitas yang sangat menonjol dalam representasi media massa di masa kini. Tubuh perempuan yang digambarkan pada iklan televisi telah menjadi alat yang sangat penting dalam berbagai proses social dan ekonomi, guna memberikan daya tarik erotis pada berbagai produk. Jika awalnya logika kapitalisme adalah berpijak pada produksi kebutuhan sebanyakbanyaknya dengan biaya produksi serendahrendahnya, kini logika itu telah bergeser menjadi "menciptakan kebutuhan melalui penciptaan citra" oleh agensi iklan. 
Dalam hal ini ikaln dan sex appeal menempati posisinya dalam kapitalisme wajah baru. Sebagaimana telah dikemukakan sebelumnya bahwa dalam system kapitalisme semua hal telah ditempatka sebagai tanda-tanda yang dapat dikomodifikasi, maksudnya diubah menjadi barang komoditas. Masalah seks selalu menjadi masalah yang up to date. Oleh karena itu, tidak mengherankan jika seks kemudian memiliki nilai komersial yang tinggi, yang akhirnya dieksploitasi oleh para produsen di berbagai bidang (Kali, 2013).

Tabloid dan berbagai aneka majalah hiburan yang menjadikan seks dan gossip sebagai andalannya banyak dibeli, terutama ketika masyarakat sudah mulai jenuh dengan berita dan kabar politik yang tak kunjung reda karena memang tak kunjung adanya penyelesaian. Hal ini bisa jadi mendorong iklan-iklan yang ada di televisi. Banyak sekali produk yang mengasosiasikan tubuh dengan produk-produk yang diiklankan.

Iklan di televisi memaparkan suatu fenomena dengan banyaknya iklan yang menampilkan model perempuan sebagai ikon produk yang dipasarkan. Perempuan yang menjadi ikon tersebut pun bukanlah perempuan yang sembarangan, namun termasuk kategori perempuan yang dicitrakan sebagai elit bisnis. Imaji kesempurnaan itu merupakan ekstraksi sumber-sumber yang terdapat pada tubuh perempuan, yang menimbulkan berupa estetika, gairah, sensualitas dan erotisme.

Piliang menyatakan bahwa tubuh tidak saja dijadikan sebagai komoditi, namun juga sebagai metakomoditi, yaitu komoditi yang digunakan untuk menjual atau mengomunikasikan komoditi-komoditi yang lainnya (Piliang, 2010). Periklanan di Indonesia telah berkembang pesat seiring berkembangnya berbagai media massa di Indonesia (Hidayat, 2015). Iklan-iklan di televisi tidak lagi sekedar alat untuk memromosikan produk terhadap konsumen, namun mendorong individu untuk melazimkan perilakunya untuk menyesuaikan apa yang dimaui oleh kreator iklan televisi. Foucault menekankan bahwa permasalahan ini sebagai kekuasaan atas kehidupan modern berbasis kapitalisme, yang mana pihak produsen mengejar keuntungan sebanyak-banyaknya melalui penjualan dan pemasaran produk yang setinggi-tingginya.

Iklan merupakan media representasi karena visual dalam bentuk gambar, tulisan dan ilustrasi pada iklan merupakan tanda dan representasi dari objek yang sebenarnya ada di dunia nyata. Contohnya adalah jika iklan memasang lukisan pemandangan alam, hal tersebut merupakan representasi alam di dunia nyata. Oleh karena tanda bersifat abritari, maka tanda - tanda tersebut merupakan hasil dari kesepakatan antara pengguna dan pemakna tanda. Dengan demikian, sering terjadi jika makna yang dihasilkan oleh consumer media dapat berbeda dari makna yang dimaksudkan oleh produsen media yang dalam hal ini adalah kreator iklan.

Begitu pula ketika iklan mengonstruksikan makna kecantikan. Iklan memberikan standard kecantikan ideal sama untuk seluruh bangsa di dunia ini. Padahal perbedaan geografis dan sistem sosial kultur tertentu menentukan standard kecantikan yang berbeda-beda. Disamping itu, sejalan dengan waktu standard kecantikan juga mengalami perkembangan dan aneka perubahan standard ukuran yang tak dapat dilepaskan dari nilai-nilai yang dianut masyarakat tertentu.

Dengan kata lain, standard kecantikan di seluruh dunia ini tak mungkin dikatakan universal. Masalahnya adalah kecantikan itu dilahirkan pada suatu kelompok tertentu dan tumbuh berkembang sejalan dengan keyakinan oleh kelompok masyarakat tersebut. Dengan demikian, makna kecantikan merupakan hasil dari konstruksi social yang mana segala sesuatunya tidak ada yang ditemukan secara serta merta namun hasil yang diproduksi oleh pelbagai kekuatan sosial.

Tiga bagian tubuh perempuan yang sering menjadi obyek dari iklan adalah wajah, rambut dan kulit. Wajah merupakan bagian tubuh perempuan yang paling unik dan bersifat publik. Rambut merupakan bagian tubuh perempuan yang memberikan simbolisasi kebebasan karena bagian tersebut dapat direka sesuai kehendak yang punya. Sedangkan kulit adalah bagian yang paling sering dijadikan obyek oleh 
iklan yang merupakan indera terpenting yang dimiliki manusia yakni indera perasa.

Selain yang bersifat fisik, kecantikan seorang perempuan pun juga dinilai dari sisi ruhaninya, yakni feminimitasnya. Hal ini Nampak pada iklan-iklan yang mempertunjukkan perempuan dengan sikap yang lemah lembut, lemah gemulai, menggoda pria dan biasanya membatasi diri pada lingkup domestic. Perempuan dituntut cantik, kurus, dan berbusana yang menarik. Ditambah pola asuh di masa lalu dimana anak perempuan diberikan boneka, kemudian meriasnya dan memperkenalkannya dengan aneka busana yang indah.

Perempuan saat ini seolah digiring untuk patuh pada norma-norma feminimitas yang mungkin dianut oleh sekelompok masyarakat tertentu. Norma penampilan fisik yang berupa wajah, tubuh, busana dan gerakan-gerakan ini dimanifestasikan dalam iklan - iklan seperti pemutih wajah, penghitam rambut, pelangsing badan dan sebagainya. Hal tersebut menjelaskan bahwa perempuan yang dapat diterima oleh masyarakat maka sudah seyogyanya mengikuti standard kecantikan yang memang berlaku di lingkungan masyarakat tersebut.

Berbagai penelitian yang berkait dengan pencitraan perempuan cantik dalam iklan. Secara umum, hasilnya menunjukkan bahwa kecantikan yang ideal dalam masyarakat yang digambarkan dalam iklan khususnya iklan televisi menunjukkan bahwa para perempuan dapat cantik seperti yang digambarkan dalam iklan, jika menggunakan aneka produk yang ditawarkan pada iklan tersebut.

Iklan-iklan yang dikaji pada penelitian ini dapat dikategorikan sebagai iklan kosmetika. Istilah kosmetika itu sendiri diambil dari bahasa Yunani yakni Kosmetikos, yang bermakna terampil dalam berdandan. Orang berdandan tujuannya adalah agar dapat tampil menarik dan cantik. Berbagai cara dapat dilakukan oleh individu untuk terlihat cantik dan menarik. Salah satunya adalah memakai produkproduk kosmetika. Menurut Undang-Undang Periklanan nomor 24 tahun 1997, pengertian kosmetika adalah campuran aneka bahan untuk digosokkan, dilekatkan, dituangkan, dipercikkan atau disemprotkan pada, dimasukkan dalam, dan digunakan pada badan manusia dengan maksud untuk membersihkan, memelihara, menambah daya Tarik atau mengubah rupa dan tidak termasuk golongan obat-obatan.

Menurut Murti (2003) macam kosmetika terdiri dari beberapa jenis dengan kegunaannya masing-masing. Antara lain adalah untuk perawatan wajah, terdiri dari bedak muka, baik yang berupa bedak padat maupun bedak tabur, susu pembersih muka, astringent, alas bedak, maskara, lipstick, lipgloss/lipbalm, pensil alis, eye shadow, pemerah pipi (blush on).

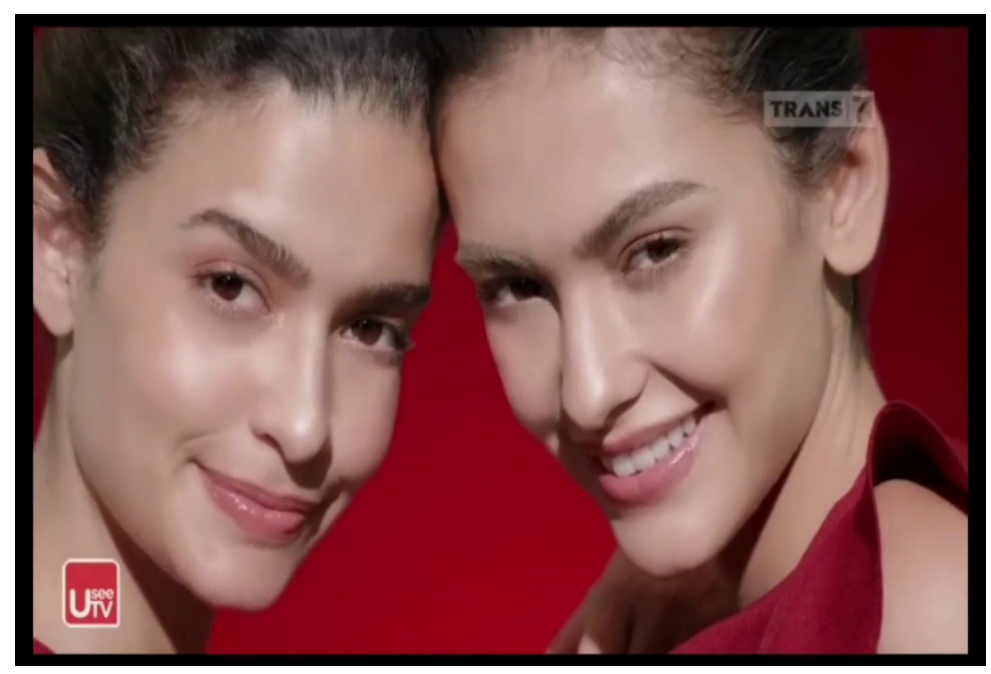

Sumber: Youtube, 2018

Gambar 1 Iklan Pond's White Beauty 
Kemudian kosmetika perawatan tubuh, terdiri dari sabun mandi, baik yang berupa sabun cair/padat, lulur, mangir, handbody lotion, bedak, parfum dan aftershave. Jenis kosmetika untuk perawatan rambut, terdiri dari shampo, shampo anti ketombe, pengeriting rambut, krim creambath, tonik atau cairan penyubur rambut, cat rambut dan lain-lain.

Berdasarkan hasil observasi, terdapat tiga jenis iklan kecantikan khusus wanita yang dikritisi di dalam penelitian ini yakni iklan pemutih wajah, iklan produk diet dan iklan shampoo. Ketiga iklan tersebut adalah iklan Pond's White Beauty versi pemotretan, iklan WRP Lose Weight dan Iklan Shampo Pantene versi Maudy Ayunda. Iklan Pond's dan juga beberapa iklan kecantikan pemutih wajah telah menggiring konsumen kaum hawa untuk memiliki kulit putih. Begitu bekennya untuk memiliki kulit putih bersih dimaknai cantik, maka banyak produsen produk kecantikan yang menghalalkan segala cara untuk dapat merancang produk kulit yang putih dan bersih.

Dalam iklan Pond's versi dua wanita yang menjadi obyek foto oleh fotografer tersebut jelas menunjukkan bahwa kulit putih lebih baik daripada berkulit yang tidak putih alias kusam/ gelap. Pada ceritera iklan tersebut dikisahkan bahwa seorang fotografer hendak mengambil dua orang gadis yang satu berkulit cerah dan yang satu berkulit kusam. Yang terjadi adalah si fotografer tersebut membidikkan kameranya ke gadis yang berkulit cerah. Hal tersebut menyebabkan gadis yang berkulit kusam menjadi sedih dan akhirnya meniatkan untuk memutihkan kulit dengan pengharapan dapat mendapatkan perhatian di kemudian hari.

Ketidaknyamanan aktor perempuan yang memeragakan kulit hitam, ditampilkan dengan wajah yang masamketika menyadari kulitnya gelap dan kusam, sementara itu, narasi iklan menyatakan bahwa pentingnya mencerahkan kulit agar Nampak menarik dan membuat orang lain terkesima. Hal tersebut menyiratkan bahwa kulit perempuan adalah sesuatu yang putih dan penuh kelembutan. Oleh karena itu, patut kiranya kulit yang gelap (dan belum tentu kusam) mendapatkan proteksi dan zat penambah agar kulit perempuan menjadi cerah.
Hal tersebut merupakan bukti nyata bahwa iklan pemutih tersebut memberikan legitimasi pembenaran bahwa kulit putih dan cerah pasti lebih indah dan cantik daripada kulit gelap. Iklan ini menyampaikan pesan bahwa pembenaran putih itu cantik adalah hasil dari konstruksi dari reproduksi kekuasaan yang kreatif dan bukan reproduksi kekuasaan yang represif. Via iklan kecantikan di televisi, perempuan yang cantik itu adalah perempuan yang berkulit putih. Lelaki umumnya menyukai perempuan yang berkulit putih. Perempuan kulit putih menjadi "obyek" pemuasan libido dari laki-laki normal dan perempuan harus tunduk pada konvensi yang ditetapkan oleh relasi kuasa iklan tersebut.

Iklan ini telah menawarkan sekaligus mempertegas hegemoni dominasi warna putih yang menyatakan kulit putihlah yang kulit yang paling indah, membawa semangat yang positif, dan memberi citra orang berkulit putih adalah orang yang selalu menjaga kebersihan dan kecantikannya. Iklan ini secara tidak langsung telah mendorong terciptanya stigma bahwa utnuk mendapatkan kulit yang membuat orang terpesona adalah kulit yang putih tentunya. Kulit putih yang biasa dimiliki oleh bangsa Kaukasus, dijadikan patokan konsep kecantikan yang ideal. Walaupun sesungguhnya yang menjadi modelnya bukanlah orang yang berasal dari ras Kaukasus namun produk tersebut ditawarkan dengan target adalah orang-orang yang berasal dari Ras Asia Timur dan Melayu.

Selanjutnya adalah iklan WRP Lose Weight dimana iklan tersebut menggambarkan seorang perempuan yang sedang bingung mencari tahu cara penggunaan produk WRP yang benar. Dengan alasan bahwa selama ini dia mencoba produk tersebut namun tidak nampak hasilnya. Sampai kemudian datang seseorang yang berbaju merah menjelaskan cara menggunakan produk tersebut yang benar. Namun demikian, perempuan yang menjelaskan tersebut melakuan gestur-gestur cenderung ke arah sensual, yang memberi tafsiran bahwa dia berhasil dalam dietnya dengan menggunakan produk tersebut.

Tafsiran iklan ini adalah bahwa kaum hawa semestinya memiliki tubuh ideal seperti halnya yang di modelkan oleh iklan WRP tersebut. Persepsi pemirsa khususnya perempuan, 


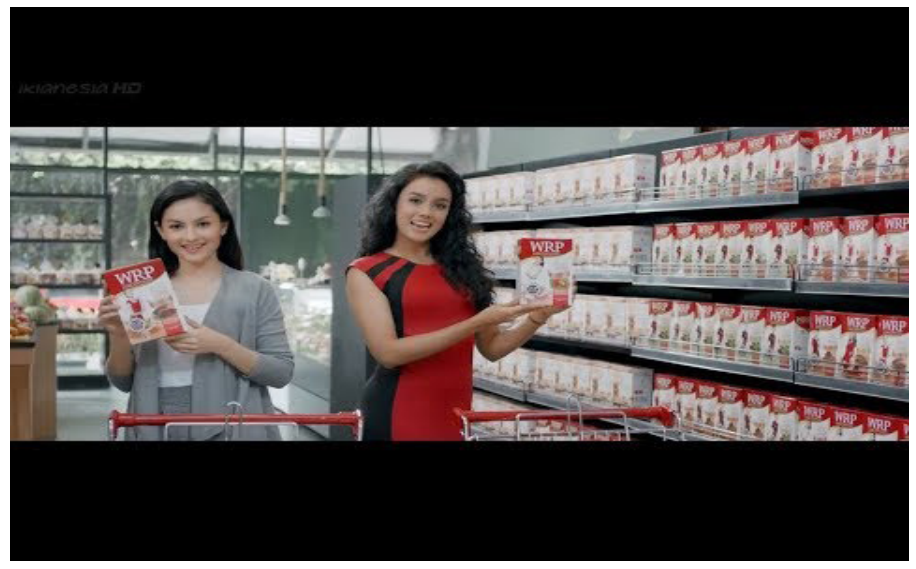

Sumber: Youtube, 2018

\section{Gambar 2 Iklan WRP Lose Weight}

diatur dan digiring untuk menjadi langsing seperti halnya model iklan WRP tersebut yang "berhasil" melewati keranjang-keranjang yang berseliweran di supermarket atau mall tersebut. Visualisasi tersebut menunjukkan bahwa untuk menjadi perempuan yang sempurna dan memiliki tubuh langsing, merupakan cara untuk memperoleh kebahagiaan dalam hidup.

Sebenarnya iklan-iklan semodel pelangsing tubuh ini sudah sering kali tidak selalu mencerminkan hasil yang nyata. Semua itu sangat tergantung dari pola perilaku penggunannya. Namun demikian iklan sejenis ini berusaha memanipulasi secara psikologis bahwa cukup menggunakan produk ini dengan sedikit mengatur pola makan, hasilnya akan membentuk tubuh idela yakni tubuh yang langsing. Beberapa penelitian dari Yayasan Lembaga Konsumen Indonesia menunjukkan bahwa pengakuan iklan pelangsing tubuh merupakan iklan yang sarat dengan pesanpesan distortif.

Produk pelangsingan sebenarnya berbagai macam jenisnya. Ada produk diuretik (menghilangkan cairan), ada produk yang melancarkan pencernaan, bahkan ada produk yang menawarkan alternatif pengganti makanan pokok namun efeknya hampir-hampir tidak ada!. Iklan ini sebenarnya menawarkan sebuah "konsep" bahwa yang terpenting adalah menjaga asupan dan olahraga yang cukup. Konsep "kesabaran untuk menunggu hasil" tidak pernah disampaikan baik secara tersirat apalagi tersurat, tidak pernah disampaikan pada iklan ini. Pesan yang disampaikan lebih menekankan bahwa tubuh perempuan ideal adalah tubuh yang langsing, tanpa mempertimbangkan sehat tidaknya produk tersebut sebagai pengganti makanan pokok.

Iklan selanjutnya adalah iklan shampoo Pantene hair fall control for vitamin versi Maudy Ayunda. Dalam iklan ini digambarkan bahwa tubuh fisik yang kuat memang harus didapat dengan latihan fisik tiap hari. Hal tersebut kemudian dianalogikan bila keramas tiap hari, akan membuat rambut lemah dan rontok. Tujuan dari iklan ini adalah mempersuasi para pemirsa perempuan untuk memiliki rambut yang kuat dan sehat. Tentunya hal tersebut tidaklah salah. Namun demikian, iklan tersebut menampilkan visualisasi ideal rambut yang kuat dan sehat adalah yang berwarna hitam, panjang dan bergelombang.

Iklan shampoo ini menyampaikan pesan awalnya adalah permasalahan pada rambut mereka. Detail kegiatan apakah aktivitasnya sebagai artis, aktivitas di jalan hingga membuat rambut menjadi sangat berdebu, sampai dengan aktivitas olahraga, menjadi faktor-faktor penyebab kerontokan rambut sang artis. Sampai pada akhir dari storyboard iklan tersebut yang menyatakan bahwa produk shampoo ini menjadi penyelesaian atas permasalahan rambut yang rontok.

Iklan shampoo perempuan di Indonesia umumnya dihubung-hubungkan dengan sosok 


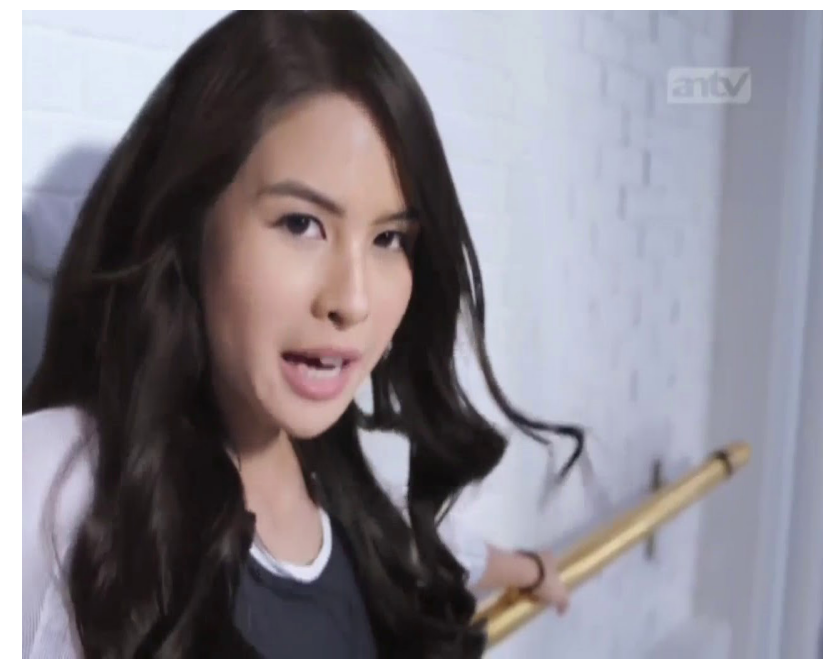

Sumber: Youtube, 2018

Gambar 3 Iklan Pantene Hair Fall Control Versi Maudy Ayunda

yang luwes dan anggun, yang dikaruniai rambut yang hitam legam bersinar. Rambut yang dimiliki oleh Maudy Ayunda menegaskan kepada para khalayak bahwa rambut yang hitam berkilau adalah ciri khas rambut yang dimiliki oleh masyarakat Melayu yang berada di Katulistiwa. Iklan ini mencoba seolah-olah mencoba meyakinkan bahwa ide pada iklan sedikit banyak "berpihak" pada kecintaan pada karakteristik alami bangsa Asia, khususnya Indonesia, dan tidak selalu "berkiblat" pada budaya Barat.

Secara tidak langsung, persepsi khalayak dibentuk untuk menggunakan produk yang sebenarnya adalah dirancang oleh Procter \& Gamble $(P \& G)$ yang berpusat di Amerika Serikat. Ini terlihat pada logo $P \& G$ yang tidak ditampilkan secara jelas dan hanya timbul pada satu detik terakhir saja. Hal ini tentunya sangat berbeda dengan brand produk dari luar negeri lainnya yang terbiasa untuk diagung-agungkan.

Pemilihan model/aktor Maudy Ayunda, dianggap mewakili sebagai representasi remaja Indonesia yang sempurna. Selain berkiprah sebagai model, biduanita dan aktris film, dia juga memiliki prestasi akademik yang cukup moncer. Disamping itu, figur Maudy yang sikapnya tidak pernah mencari sensasi atau atau berperilaku kontroversial seperti halnya beberapa artis Indonesia lainnya. Produk shampoo ini tentunya berharap bahwa
Maudy dapat menjadi teladan yang baik bagi masyarakat, khususnya bagi remaja putri Indonesia seusianya dan sebayanya.

Dengan demikian, publik akan tidak segan untuk mengikuti apapun yang digunakan oleh pujaannya, mulai dari perilakunya, prestasinya, fesyen sampai dengan produk kosmetika yang digunakannya. Pada akhirnya terbentuklah ikon yang dapat mencerminkan shampoo Pantene sebagai produk yang digunakan oleh teladan perempuan muda yang memiliki bukan saja kecantikan dari luar (fisik) saja, namun juga kecantikan dalam yakni dengan segala prestasinya.

Kembali ke masalah inti dari iklan produk shampoo tersebut, tersirat bahwa merawat rambut adalah suatu kegiatan yang barangkali membosankan bagi perempuan yang memiliki karir. Biasanya mereka tidak memiliki waktu senggang untuk bersantai dan merawat rambut mereka. Pantene mencoba melihat ini sebagai suatu peluang sekaligus tantangan untuk mempromosikan keunggulan produknya. Cukup berkeramas setiap hari, maka yang didapatkan adalah rambut yang terawat selama tiga bulan. Dengan demikian, ilustrasi pada iklan semakin meyakinkan kepada konsumennya bahwa penggunaan produk ini dapat memperbaiki rambut yang tak terawatt menjadi lebih sehat.

Iklan shampoo tersebut menampilkan visualisasi dimana rambut perempuan yang 
sehat adalah rambut yang tidak pecah dan bercabang. Jika para remaja putri hendak tampil dengan rambut yang memesona maka sosok yang dapat ditiru adalah sosok yang menjadi bintang iklan tersebut. Pantene menjadi satusatunya shampoo yang memberi standard untuk rambut sehat dan kuat serta tak mudah rontok. Hegemoni atas tindakan pengiklan guna meyakinkan pikiran khalayak, menjadi ideologi setiap pesan yang disampaikan iklan adalah suatu tindakan pembenaran untuk menjadikan rambut sehat khas bangsa Indonesia. Ideologi ini pada akhirnya memengaruhi alam bawah sadar para pemirsanya untuk mengikuti kehendak si produsen shampoo tersebut.

Tubuh yang kurus, kulit yang putih bersinar, dan rambut hitam yang lurus/bergelombang dan berkilau pada akhirnya menjelma menjadi diskursus dominan fisik perempuan yang ideal di benak khalayak kita. Diskursus ini mampu menggusur serta meminggirkan diskursus alternatif yakni bagi para perempuan yang tidak berkulit bening, berambut hitam berkilau dan bertubuh tidak langsing. Konsekwensinya adalah bagi para perempuan yang tak mendapatkan "status" sebagaimana yang telah justifikasi iklan, akan kehilangan kepercayaan pada diri kuasa atas fisiknya serta seiring berjalannya waktu memudarnya identitas ciri akan fisiknya, yang dengan mudahnya akan terabaikan.

Dengan demikian, iklan kosmetika dan perawatan kulit di televisi merupakan salah satu kultur pop yang menciptakan perubahan sosial tatanan masyarakat. Koenig (dalam Soekanto, 2002:305) menyatakan bahwa perubahan sosial dapat terbentuk dari modifikasi yang terjadi dalam pola-pola kehidupan manusia. Iklan di televisi telah mengubah pola konsumsi masyarakat modern walaupun tidak semua. Namun demikian, ada hal-hal yang perlu diperhatikan yakni bahwa konsep penampilan secara fisik yang perlu dimiliki oleh perempuan, apabila ingin ditaksir oleh laki-laki. Di samping itu, sebaliknya untuk menjadi kaum Adam, mereka dijejali standard perempuan yang cantik yang layak untuk menjadi mitra mereka.

Beberapa kelompok masyarakat berpendapat bahwa kultur pop atau budaya popular merupakan tanda kemajuan dari suatu peradaban, terutama yang berasal dari budaya barat. Namun demikian pengaruh yang ditimbulkan oleh kultur pop yang berasal dari proses modernisasi dan hasil produk kapitalisme ini sangat memberi dampak yang kurang baik bagi beberapa pihak. Diantaranya adalah eksistensi kultur lokal yang pada akhirnya makin memudar dengan alasan tidak kekinian dan identitas diri yang makin tergerus oleh karena standarisasi dari globalisasi sebagai "pihak" perekayasa kultur modern.

Pada akhirnya, kultur pop dapat dikatakan sebagai budaya komodifikasi. Dikatakan demikian oleh karena produk budaya ini dihasilkan secara massal yang bertujuan untuk mendapatkan profit ekonomis semata. Dengan demikian, hal tersebut memberikan dampak yang kurang baik bagi masyarakat. Alasannya adalah bahwa penilaian baik buruknya suatu produk kultur bukan lagi berdasarkan pada moralitas dan nilai-nilai luhur, namun pada hasrat ekonomi untuk mendapatkan gengsi dan pengakuan yang semu.

Di samping itu, produk-produk yang dihasilkan kultur pop cenderung merusak budaya dan sistem tata krama dan kearifan lokal dalam kehidupan masyarakat yang genuine. Kultur Pop mendorong masyarakat menjadi pasif dalam aksinya karena semua kebutuhan hidup sudah tersedia di depan mata. Segala evaluasi baik buruk, positif negatif, akurat bias dan segala panduan dalam tuntunan hidup sudah ditentukan oleh industri pop kultur.

Segala bentuk nilai-nilai yang terkandung dalam pop kultur akan mendorong masyarakat untuk menghabiskan uang, demi kepemilikan produk kultur pop yang diinginkannya. Hal ini sejalan dengan apa yang dinyatakan oleh Walter Lippmann, bahwa saat ini kita hidup di desa global, yang mana kultur pop telah menjadi bagian dari identitas warga yang menghuni desa global tersebut. Kultur pop telah menghalau masyarakat pada pendangkalan makna. Industri pop kultur telah memproduksi kultur yang homogen melalui standar karakter dan identifikasi persona yang diakui secara ideal. John Fiske juga mengemukakan teori tentang kode-kode televisi (the codes of television). 
Menurut Fiske, kode-kode yang muncul atau yang digunakan dalam acara televisi saling berhubungan sehingga terbentuk sebuah makna (Diani, Lestari, dan Maulana, 2017).

Hal ini terwujud sebagai contohnya yakni evaluasi dan konstruksi mengenai makna "Cantik" yang awalnya dianggap suatu yang nisbi, saat ini hal tersebut distandarisasi oleh industri kultur pop melalui berbagai produk kosmetika yang diiklankan terutama di televisi. Kertamukti menyebutkan bahwa dalam dunia siber, tubuh terprogramkan, identitas terkonstruksi dalam wujud digital. Tubuh hadir secara audio visual dan kinestetis dalam ruang monitor (Kertamukti, 2018). Widyatama menyebut isi pesan komersial cenderung mengkonstruk penampilan secara stereotip yang klise, timpang dan sering kali tidak benar atau bias gender (Puspita dan Nurhayati, 2018).

Konsekuensinya adalah meningkatnya kegalauan disertai kekhawatiran yang meningkat dari para perempuan di negeri ini karena selalu merasa ada yang tidak lengkap pada dirinya secara psikologis dan secara fisik. Hal ini disebabkan karena determinasi nilainilai oleh industri kultur pop selalu memberikan tekanan pada perspektif negatif, yang mana memublikasikan rekayasa aneka kekurangan fisik yang nantinya akan dipenuhi oleh produkproduk industri, terutama industri kosmetika modern.

Dampak yang tidak terantisipasinya adalah menimbulkan rasa percaya diri yang rendah bagi banyak perempuan. Tidak sedikit para kaum hawa yang ikhlas berkorban dan melakukan segala cara untuk mendapatkan wajah yang rupawan (putih), dengan rela melakukan diet yang sebegitu ketat agar tubuh yang dimilikinya terlihat ramping, sesuai dengan apa yang digambarkan di televisi. Seolah-olah televisi sebagai salah satu perangkat keras industri kultur pop sudah memberikan advis yang solutif terhadap segala permasalahan yang berhubungan dengan fisik wanita yang dianggap "pasti ada kurangnya".

Hal ini justru akan mendorong hilangnya identitas "unik" pada persona perempuan sebagai individu. Kebanggan akan timbul apabila individu tersebut bias tampil layaknya seperti idolanya alih-alih menunjukkan ciri khas diri pribadinya sendiri. Karakter manusia yang awalnya unik menjadi uniform, sejalan dengan sejumlah standard yang telah dikonstruksi oleh industri kultur pop. Tiada lagi pemahaman yang mendalam apa yang sejatinya "katastrop"media lakukan pada dirinya saat ini, khususnya pada dampak televisi yang mendangkalkan pemahaman dinamika kehidupan manusia.

Iklan telah memberikan penekanan pada anggota tubuh perempuan yang mana yang harus dipoles agar individu yang bersangkutan dapat menyesuaikan standard kecentikan tertentu. Misalnya muka, rambut, leher, punggung, tangan atau kaki. Iklan berusaha untuk mengubah pandangan kebudayaan, yang mana satu kebudayaan dengan kebudayaan lain tentunya berbeda di dalam menentukan cara pandang dan pola hidup kelompok masyarakat yang menganut budaya tersebut, termasuk di dalamnya adalah makna terhadap kecantikan.

Tentunya ada kesamaan dan ada perbedaan antara budaya yang satu dengan yang lain dalam memaknai kecantikan. Dalam kesamaan cara memaknai kecantikan misalnya wajah yang simetris dan penuh senyum, dapat diakui oleh semua bangsa bahwa hal tersebut merupakan bagian dari kecantikan. Namun demikian, banyak juga perbedaan yang dapat kita temui mengenai makna kecantikan. Sebagai contoh, masyarakat Asia Timur (Tiongkok, Korea dan Jepang) beranggapan bahwa perempuan yang memiliki mata yang lebar dapat dianggap cantik. Padahal mereka rata-rata memiliki muka yang cenderung bulat dan mata yang cenderung sipit. Hal tersebut justru menjadi kontradiksi.

Kontradiksi tersebut juga dialami oleh orang-orang Barat yang memiliki ras Kaukasus. Mereka justru cenderung menilai bahwa kulit coklat keemasan yang terpapar sinar matahari merupakan tanda kecantikan seseorang. Hal tersebut dimanfaatkan oleh para produsen untuk menjual produk pencoklat kulit bagi perempuan ras Kaukasus dan sebaliknya menawarkan produk pemutih bagi perempuan Asia, termasuk Indonesia.

Dalam temuan di atas misalnya, iklan Pond's menyatakan bahwa tujuan akhir dari penggunaan produk yang diitawarkan adalah 
kulit yang bersih, kulit yang putih. Hal ini sejalan dengan tujuan akhir dari para pelaku yang tergambar di storyboard iklan tersebut. Iklan ini juga telah menegaskan kepada masyarakat Asia, akan superioritas bangsa yang berkulit putih terhadap kulit warna. Sejarah mencatat bahwa sistem taksonomi Linnaeus (17071778) yang membagi empat kelompok bangsa manusia berdasarkan ras nya, yakni bangsa berkulit hitam, kulit merah, kulit kuning dan kulit putih, dilandasai oleh pembagian wilayah geografis. Bangsa kulit hitam yang diwakili oleh bangsa Afrika, kulit merah oleh bangsa Indian Amerika, kulit kuning oleh bangsa Asia dan kulit putih oleh bangsa Eropa.

Superioritas makin berkembang di kala era kolonialisme dan perbudakan. Terlebih ketika bangsa Eropa menguasai benua Amerika dan Australia. Atribut fisik yang mirip bangsa Eropa dianggap lebih beradab dan lebih disenangi dibandingkan bangsa yang berkulit warna selain putih. Terlebih lagi jika bangsa yang berkulit hitam dan gelap dianggap lebih bodoh dan tidak beradab. Dengan demikian, ditinjau dalam konteks kolonialisasi, warna kulit pun danggap dapat menentukan strata kelompok sosial.

Difusi mengenai ide stereotype perbedaan warna kulit itu tidak hanya bersifat individual, tetapi juga pada skala yang lebih luas yakni bersifat massif. Iklan televisi juga akhirnya harus diakui bahwa ia adalah medium yang tidak hanya sekedar memasarkan suatu produk untuk menghasilkan keuntungan bagi produsennya, namun juga membawa misi-misi tertentu yakni antara lain adalah mengonstruksi ide atau konsep tertentu dengan cara sedemikian rupa, agar konsumen meyakini bahwa apa yang mereka tonton merupakan sebuah kebenaran tak terbantahkan. Representasi yang ditampilkan dalam media massa elektronik, baik itu film ataupun televisi, menghadirkan suatu realita yang disaksikan oleh para pemirsanya, dan bukan hanya sekedar aktivitas "sedang menonton televisi".

Studi - studi feminisme juga menunjukkan bahwa konstruksi kecantikan yang ideal kontemporer, berbasiskan ideologi patriarki. Kecantikan merupakan hal yang harus diusahakan oleh para perempuan untuk "melayani" kepuasan kaum Adam. Padahal, terjadinya eksploitasi tubuh perempuan yang berujung pada komodifikasi merupakan sebuah ironi. Alasannya adalah manusia haruslah diperlakukan sebagai manusia, yakni sebagai subyek yang memiliki akal budi dan kehendak serta kebebasan. Manusia tidak boleh diperalat sebagai obyek. Namun yang terjadi adalah saat ini, iklan berusaha untuk selalu menumbuhkan aneka kecemasan serta kekurangan tubuh yang dimiliki perempuan. Kesinambungan antara konsep kecantikan dan komoditas telah dikerjakan secara baik oleh iklan, terutama iklan televisi.

\section{SIMPULAN}

Televisi telah membius pemirsanya, terutama para pemirsa perempuan. Apalagi bagi pemirsa yang menghabiskan berjam-jam untuk menonton televisi di rumahnya. Secara eksklusif, televisi telah mentransmisikan dua pesan ideologi yang menggiring pada kesesatan pemirsa kaum hawa yang antara lain sebagai berikut. Pertama, Televisi mencoba untuk menyakinkan bahwa budaya modern yang dominan telah sahih dikonfirmasikan melalui mitologi dan ideologi kapitalisme untuk disajikan secara massif. Kedua, menerapkan budaya individual ke dalam aneka sistem yang dominan sehingga tidak dianggap terkucil dari dunia modern.

Selanjutnya, televisi telah mendeseminasi aneka makna yang diproduksi ke segenap lini anggota masyarakat yang lebih mengglobal. Kemudian, televisi mempertegas garis besar hegemoni budaya yang lebih mapan mengenai hakikat dari realitas. Televisi melakukan selebrasi budaya individual yang dianggap mewakili ke dalam dunia global dan modern. Televisi pula berusaha menyamakan status pihak dominan dan identitas individu yang digaransi oleh budaya dominan. Terakhir, televisi menampilkan nilai "rasa" dari budaya tersebut sendiri menjadi hasil dari kondisi kultur yang berubah pada dunia global.

Sejatinya, televisi tidak menampilkan kebutuhan perempuan, namun justru kebutuhan 
dari para pembuat iklan. Oleh karena itu, perempuan perlu direkayasa dalam terminologi kaum Adam untuk mendukung kepentingan para pemilik industri kecantikan modern. Perempuan harus menjadi obyek yang dapat menjadi individu yang menghamba pada kehidupan masyarakat industrialis dan sasaran masyarakat yang over konsumtif. Yang terjadi saat ini adalah individu perempuan semakin direfleksikan dalam ketidakadilan pendivisian jender dalam sistem sosial yang ada.

Komunikasi pemasaran melalui iklan tidak lagi menawarkan produk secara terang-terangan dan kaku, namun juga melalui eksekusi caracara yang kreatif dan menarik. Iklan tidak hanya memberikan informasi tentang produk berupa barang dan jasa, namun juga meluaskan pada suatu pengkondisian situasi dan kondisi tertentu pada suatu strata dan kelompok masyarakat.

\section{DAFTAR PUSTAKA}

Borton, G. (2008). Media dan budaya populer, Yogyakarta: Jalasutra.

Cobley, P (Ed). (2006). Communication theories, New York: Routledge.

Diani, A., Lestari, Martha, T. L., \& Maulana, S. (2017). Representasi feminisme dalam film maleficent. ProTVF. 1(2). 139-150. DOI: https://doi.org/10.24198/ptvf.v1i2.19873.

Eriyanto. (2001). Analisis wacana:pengantar analisis teks media. Yogyakarta: LKiS.

Fiske, J \& Hartley, J. (2003). Reading television. New York: Routledge.

Haryatmoko. (2010). Michael Foucault dan politik kekuasaan: membongkar teknik, mekanisme, dan strategi kekuasaan. Jakarta: Gramedia Pustaka Utama.
Hidayat, D. R. \& Abdullah, A. (2014). Fenomena iklan baris kesehatan di surat kabar lokal. Jurnal Kajian Komunikasi. 2(2). 138-147. DOI: https://doi.org/10.24198/jkk.v2i2.7380.

Hidayat, D. R. (2015). Dinamika iklan pengobatan alternatif di televisi. Jurnal Kajian Komunikasi. 3(2). 112-119. DOI: https://doi.org/10.24198/ jkk.v5i1.7432.

Kertamukti, R. (2018). Komunikasi visual: fantasi tubuh wanita kelas menengah di Instagram. Jurnal Kajian Komunikasi. 6(2). 231-246. DOI: https://doi.org/10.24198/jkk.v6i2.17925.

Mc Quail, D. (2002). Teori komunikasi massa, Jakarta: Erlangga.

Murti, S. K. (2003). Persepsi remaja putri terhadap penayangan iklan kosmetika di televisi. Skripsi. Jurusan Ilmu-ilmu Sosial Ekonomi Pertanian. Bogor: Institut Pertanian Bogor.

Pantene. (2018). Iklan pantene hair fall control versi maudy ayunda. Diakses dari https://www. youtube.com/watch? $\mathrm{v}=\mathrm{ux} 7 \mathrm{WLP}-8 \mathrm{wGw}$.

Permana, S. M. P., Abdullah, A., Mahameruaji, J. M. (2019). Budaya menonton televisi di Indonesia: dari terrestrial hingga digital. ProTVF 3(1). 53-67. DOI: https://doi.org/10.24198/ptvf. v3i1.21220.

Pond's. (2018). Iklan pond's white beauty. Diakses dari https://www.youtube.com/ watch? $\mathrm{v}=$ sMEHKrsjSKs.

Puspita, D. F. R., \& Nurhayati, I. K. (2018). Analisis semiotika John Fiske mengenai realitas bias gender pada iklan kisah Ramadhan Line versi adzan ayah. ProTVF. 2(2). 157-171. DOI: https://doi.org/10.24198/ptvf.v2i2.20820.

Strinati, D. (2003). Popular culture (Edisi Terjemahan). Yogyakarta: Bentang.

Soekanto, S. (2002). Sosiologi: suatu pengantar, Jakarta: Rajagrafindo Perkasa.

WRP. (2018). Iklan wrp lose weight. Diakses dari https://www.youtube.com/ watch? $\mathrm{v}=\mathrm{cC} 1 \mathrm{nxzvkwI8}$. 